\title{
Croton campanulatus (Euphorbiaceae s.s.), a new species from the Brazilian Atlantic rain forest
}

\author{
Maria Beatriz Rossi Caruzo ${ }^{1,3}$, Ricarda Rina ${ }^{2}$, Inês Cordeiro ${ }^{3}$, And \\ PAUL E. BERRY ${ }^{2}$ \\ ${ }^{1}$ Departamento de Botânica, Instituto de Biociências, Universidade de São Paulo, Cx. Postal \\ 11461, 05422-970, São Paulo, São Paulo, Brazil; e-mail: mbrcaruzo@hotmail.com \\ ${ }^{2}$ University of Michigan Herbarium, 3600 Varsity Drive, Ann Arbor, MI 48109-2287, USA \\ ${ }^{3}$ Instituto de Botânica, Secretaria do Meio Ambiente, Cx. Postal 3005, 01061-970, São Paulo, \\ São Paulo, Brazil
}

\begin{abstract}
Croton campanulatus, a new species from southeastern Brazil in the states of Minas Gerais and Rio de Janeiro, is here described and illustrated. Morphological data indicate that this species belongs to Croton section Cleodora based on its arborescent habit, pistillate flowers with imbricate sepals, reduced petals, and multifid styles that are fused at the base.
\end{abstract}

Key Words: Atlantic rain forest, Brazil, Croton, Croton section Cleodora, Euphorbiaceae.

Croton L. is the second largest genus in the family Euphorbiaceae, with an estimated 1223 species (Govaerts et al., 2000). The genus occurs mostly in tropical regions worldwide, but also has some representatives in subtropical and northern temperate areas. In the Neotropics, its centers of diversity are Brazil, the West Indies, and Mexico (Burger \& Huft, 1995). In Brazil, Croton is represented by around 300 species, including herbs, shrubs, and trees occupying all types of vegetation, but with the greatest number of species concentrated in the eastern part of the country.

Croton campanulatus, a new species of Croton sect. Cleodora (Klotzsch) Baill., is known from the Brazilian states of Minas Gerais and Rio de Janeiro, where it grows in montane areas of Serra da Mantiqueira, in Atlantic rain forest.

Croton campanulatus Caruzo \& Cordeiro, sp. nov. Type: Brazil. Rio de Janeiro: Município de Itatiaia, Parque Estadual do Itatiaia, estrada para a piscina do Maromba, ao longo da estrada, $950 \mathrm{~m}, 22^{\circ} 26^{\prime} 10^{\prime \prime} \mathrm{S}$, 4436'49.4"W, mata atlântica, 6 Feb 2006, M. B. R. Caruzo, R. Riina \& N. Camps 93 (holotype: SP; isotypes: K, NY, WIS).

(Fig. 1)

Crotoni hemiaryreo Müll. Arg. affinis sed indumento rufo-argenteo, foliis ad margines integeris, stipulis caducis, bracteis ovato-lanceolatis, staminibus circa 25 , floribus femineis majoribus, stylis inclusis differt.

Tree 4-5 m tall, monoecious, indument rufous-silvery, lepidote trichomes without a central ray, those pale, reddish or sometimes with a reddish center and a pale margin, 0.3$0.5 \mathrm{~mm}$; branchlets cylindric, strongly striate, rufous-silvery, covered by reddish and scattered pale trichomes. Leaves alternate; lamina $3.5-17.5 \times 1.5-9.5 \mathrm{~cm}$, ovate, discolorous, upper surface green with scattered pale trichomes and lower surface silvery with scattered reddish trichomes or trichomes with a reddish center and a pale margin, apex acuminate, base rounded to truncate, margin entire, upper surface lepidote, lower surface densely lepidote, venation pinnate, brochidodromous, secondary veins 4-6, abruptly upturned towards the next ones, tertiary veins percurrent; petiole $1.5-9 \mathrm{~cm}$ long, with a pair of stalked acropetiolar glands; stipules decid- 


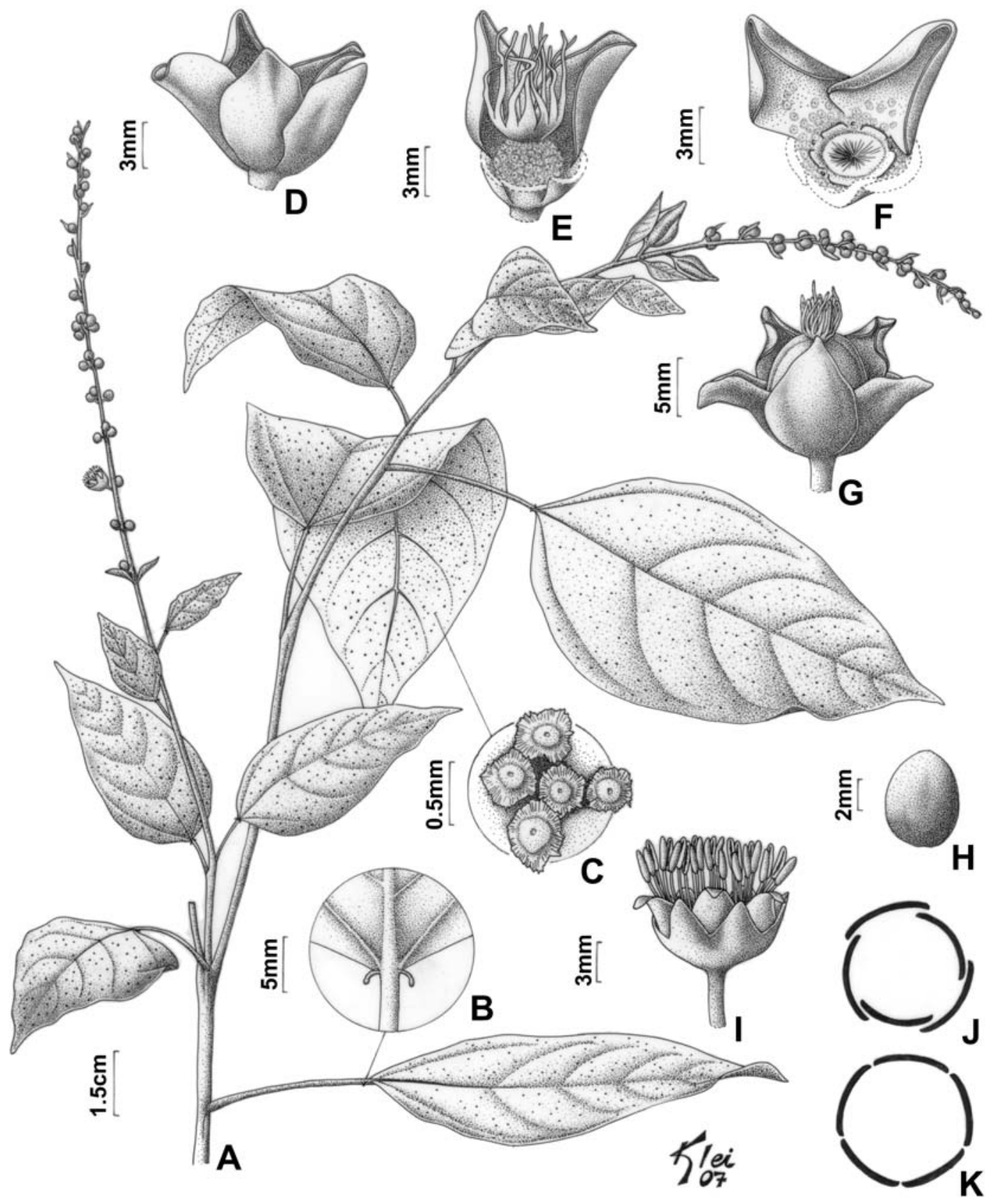

Fig. 1. Croton campanulatus. A. Branch with inflorescences. B. Detail of stalked acropetiolar glands. C. Lepidote trichomes. D. Pistillate flower. E. Gynoecium. F. Detail of pistillate flower disk. G. Fruit. H. Seed. I. Staminate flower. J. Pistillate flower aestivation. K. Staminate flower aestivation. (Drawn from the holotype.)

uous. Inflorescence 4-12 cm long, terminal, without interruption between the pistillate and staminate cymules; inflorescence axis appressed, striate, lepidote; proximal cymules bisexual, with 1 pistillate flower and 2 staminate flowers, distal cymules with 3 staminate flowers; bracts 4-9 mm long, ovate-lanceolate, prophylls 1-2 mm long, lanceolate. Staminate 
flowers 8-10 mm long, campanulate, pedicels 2-3 mm long; calyx 3-4 mm long, lepidote externally, rufous-silvery, covered by reddish and scattered pale trichomes, glabrate internally; calyx lobes united half of their length, 1.5$2 \mathrm{~mm}$ long, entire, equal, valvate, ovate, apex acute; petals $5 \mathrm{~mm}$ long, spathulate, apex obtuse to rounded, lepidote externally; disk 5-segmented; stamens ca. 25, filaments subulate; receptacle villous with simple trichomes. Pistillate flowers $8-10 \mathrm{~mm}$ long, campanulate, not fleshy, sessile to short pedicellate; calyx 7-9 mm long, lepidote externally, rufous-silvery, covered by reddish and scattered pale trichomes, glabrate internally; sepals 5, 7-9 $\mathrm{mm}$ long, equal, quincuncial, broadly ovate, not fleshy; petals reduced to glands; disk entire, deeply 5-lobed; ovary globose, lepidote; styles 3, tetrafid, slightly joined at the base, inserted. Capsules 10$15 \mathrm{~mm}$ long, globose, lepidote, calyx strongly accrescent and inflated, covering the young fruit, pedicel slightly accrescent; seeds 6-8 mm long, globose-elliptic, smooth.

Distribution and habitat.-Brazil, in Minas Gerais and Rio de Janeiro states (Fig. 2). Croton campanulatus is found along streams and roadsides in montane rain forests of the Mata Atlântica region, between 900 and $1500 \mathrm{~m}$ elevation. The species grows in sympatry with other arborescent species of Croton, namely Croton organensis Baill. (another member of sect. Cleodora) and $C$. vulnerarius Baill. (sect. Cyclostigma Griseb.).

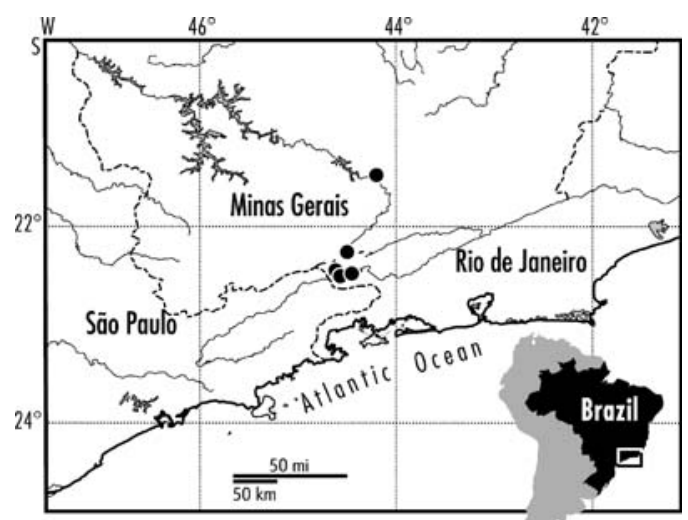

FIG. 2. Geographical distribution of Croton campanulatus.
Etymology.-The specific epithet of this new species refers to its campanulate calyx, present in both staminate and pistillate flowers.

Additional specimens examined. BRAZIL. MinAS GeraIs: Bocaina de Minas, distrito de Mirantão, margem esquerda do rio Preto, fazenda Mauá, ca. de 1500 m, 9 Jan 1988, Pineschi 348 (GUA); Piedade do Rio Grande, córrego das águas limpas, 17 Nov 1990, Souza s.n. (R). RIO DE JANEIRO: Itatiaia, 30 May 1935, A.C. Brade 14650 (RB, MG); Itatiaia, Parque Estadual do Itatiaia, entre a piscina do Maromba e a ponte do Maromba, às margens do rio Campo Belo, $1100 \mathrm{~m}$, Mata Atlântica, 6 Feb 2006, Caruzo et al. 94 (SP, SPF, WIS); Itatiaia, Hotel Donati, 20 Apr 1962, Castellanos 23418 (GUA); Parque Nacional de Itatiaia, 5 Mar 1948, Cunha Mello s.n. (RB); Itatiaia, Parque Nacional de Itatiaia, Três Picos, 1200 m, 27 Mar 1948, Cunha Mello s.n. (RB); Itatiaia, 8 Jan 1947, Duarte \& Pereira s.n. (MG, RB); Serra da Mantiqueira, Itatiaia, National Park, N of Itatiaia, roads to and environments of Maromba falls, 900 m, 5 Sep 1973, Ehrendorfer \& Gottsberger 73905-22.40 (DAV); Rezende, Parque Nacional de Itatiaia, perto do Museu e do abrigo $\mathrm{n}^{\circ}$ 21, 18 Oct 1977, Ferreira \& Briolanjo 157 (RB, SP); Itatiaia, 20 Jan 1873, Glaziou 6679 (P); Itatiaia, Parque Nacional de Itatiaia, Ponte do Maromba, 11 Aug 1997, de Lima 399 (RB); Itatiaia, P. Nacional, 950 m, 4 Mar 1962, Pereira 6974 (MBM, HB); Itatiaia, Parque Nacional de Itatiaia, Trilha do Hotel Simon para os três picos, $1200 \mathrm{~m}$, $22^{\circ} 15^{\prime}-22^{\circ} 28^{\prime} \mathrm{S}$ e $44^{\circ} 34^{\prime}-44^{\circ} 45^{\prime} \mathrm{W}, 18$ May 1999 , Quinet 201 (RB); Itatiaia, Hotel Donati, 21 Apr 1962, Strang 411 (GUA, DAV); Itatiaia, Hotel Donati, Sep 1964, Strang s.n. (GUA, DAV); Itatiaia, Parque Nacional de Itatiaia, Trilha do Hotel Simon para os três picos, 9 Nov 1997, Sylvestre et al. 918 (RB).

Following the sectional synopsis of Croton by Webster (1993), the new species fits the morphological definition of Croton section Cleodora (Klotzsch) Baill. by virtue of its arborescent habit, pistillate flowers with imbricate sepals, reduced petals, and multifid styles. In addition to these characters indicated by Webster (1993), members of section Cleodora have the styles fused at the base, as in Croton campanulatus, or fused almost half of their length in some other species.

Among the other species of section Cleodora, Croton campanulatus is morphologically most similar to $C$. hemiargyreus Müll. Arg., a species with an apparently disjunct distribution, from dry forests in southeastern Brazil (São Paulo, Minas Gerais and Rio de Janeiro) and from the state of Pernambuco in northeastern Brazil. Croton campanulatus differs from $C$. hemiargyreus in several features as indicated in Table I. In addition, several herbarium collections of Croton cam- 
TABLE I

Main Characters distinguishing CRoton Campanulatus From C. hemiargyreus and C. Salutaris.

\begin{tabular}{|c|c|c|c|}
\hline Character & C. campanulatus & C. hemiargyreus & C. salutaris \\
\hline Indument & rufous-silvery & silvery & silvery \\
\hline Trichomes & $\begin{array}{c}\text { lepidote without } \\
\text { a central ray }\end{array}$ & $\begin{array}{c}\text { lepidote without } \\
\text { a central ray }\end{array}$ & $\begin{array}{l}\text { lepidote-porrect } \\
\text { (with a central ray) }\end{array}$ \\
\hline Leaf margin & entire & finely serrate & entire \\
\hline Stamen number & ca. 25 & ca. 15 & ca. 15 \\
\hline Pistillate flower attachment & sessile to short pedicellate & short pedicellate & pedicellate \\
\hline Pistillate flower length & $8-10 \mathrm{~mm}$ & $5-6 \mathrm{~mm}$ & $7-8 \mathrm{~mm}$ \\
\hline Pistillate flower shape & campanulate & campanulate & flask-shaped \\
\hline Pistillate calyx length & $7-9 \mathrm{~mm}$ & $3-4 \mathrm{~mm}$ & $3-4 \mathrm{~mm}$ \\
\hline Pistillate calyx lobes & not fleshy & fleshy & fleshy \\
\hline Pistillate sepals in fruit & strongly accrescent, inflated & strongly accrescent, not inflated & $\begin{array}{c}\text { neither accrescent } \\
\text { nor inflated }\end{array}$ \\
\hline Styles & included & exserted & exserted \\
\hline Habitat & montane rain forest & dry forest & montane rain forest \\
\hline
\end{tabular}

panulatus have been erroneously identified as Croton salutaris Casar. (another member of sect. Cleodora), but the two species can easily be separated by several floral and vegetative characters (Table I).

Molecular data based on the ITS and the chloroplast $\operatorname{trn} L-F$ regions, individually and in combination, give results consistent with morphology and indicate that Croton campanulatus belongs to sect. Cleodora (Caruzo et al., in prep).

\section{Acknowledgments}

Thanks are due to Klei Rodrigo Souza for the illustrations, Kandis Elliot for the map and formatting of the illustration, Mário Gurgel Filho for revising the Latin description, Hajo Esser for reviewing the manuscript, and the CNPq for the fellowship awarded to the first author. Financial support for a field trip to Brazil was provided to the second author by The Lawrence Memorial Award from the Hunt Institute for Botanical Documentation, the William R. Anderson Graduate Student Research Grant Fund from the American Society of Plant Taxonomists (ASPT), and the U.S. National Science Foundation (award \# DEB-0212481 to P. Berry).

\section{Literature Cited}

Burger, W. \& M. Huft. 1995. Flora costaricensis: Euphorbiaceae. Fieldiana Botany 36: 1-169.

Govaerts, R., D. G. Frodin \& A. Radcliffe-Smith. 2000. World checklist and bibliography of Euphorbiaceae (and Pandaceae). 4 vols. Royal Botanic Gardens, Kew, England.

Webster, G. L. 1993. A provisional synopsis of the sections of the genus Croton L. (Euphorbiaceae). Taxon 42: 793-823. 